\begin{tabular}{|c|c|c|c|c|}
\hline Treatment & $\begin{array}{c}\text { Total side- } \\
\text { chain carboxyl }\end{array}$ & $\begin{array}{c}\text { Glutanic } \\
\text { acid }\end{array}$ & $\begin{array}{c}\text { Aspartic } \\
\text { acid }\end{array}$ & $\begin{array}{c}\text { Amide- } \\
\text { nitrogen }\end{array}$ \\
\hline $\begin{array}{c}\text { None } \\
\text { Methyl magnes- } \\
\text { ium iodide }\end{array}$ & 1.24 & 0.75 & 0.47 & 0.26 \\
$\begin{array}{c}\text { Lithium alum- } \\
\text { inium hydride }\end{array}$ & 1.05 & 0.62 & 0.40 & 0.25 \\
\hline
\end{tabular}

yielded the results shown in the accompanying table (expressed as m.mole/gm. dry protein).

It is seen that treatment of the methylated collagen with methyl magnesium indide brings about a small reduction in the number of side-chain carboxyl groups. Lithium aluminium hydride, on the other hand, appears to effect more extensive reduction of the carboxyl group. In accordance with the work of Morrison et al. ${ }^{4}$, some reduction of the amide groups was also observed.

It is hoped to publish full details of this work in the Journal of the Society of Leather Trades Chemists. ROBERT L. SYKES*

Department of Leather Industries, University, Leeds 2.

\section{Oct. 8.}

* Present address : C/o F. A. Hides, Tanning and Allied Industries Bureau, P.o. Box 1091, Nairobi.

'Fox, "Advances in Protein Chemistry", 2, 156 (1945).

2 Fromageot, Jutisz, Meyer and Penasse, Biophys. et Biochim. Acta, 6, $283(1950)$.

${ }^{3}$ Consden, Gordon and Martin, Biochem. J., 42, 443 (1948).

4 Morrison, Long and Konigstein, J. Chem. Soc., 952 (1951).

\section{Determination of Glycerol in Fermentation Solutions : a Rapid Chromatographic Procedure}

A RAPID and simple chromatographic procedure has been developed in this laboratory for the determination of glycerol in solutions obtained by the sulphite fermentation process of Cuban blackstrap molasses, and it is considered that the method may have wider applications. Neish ${ }^{1}$ has described a chromatographic procedure for the determination of glycerol present in amounts up to about $5 \mathrm{mgm}$. in small samples of fermentation solutions. 'The present method is suitable for the determination of glycerol which may be present in amounts of the order of $500 \mathrm{mgm}$., thus permitting the use of a volumetric procedure for the final determination of glycerol.

It has been shown that glycerol is readily separated from sugars by partition chromatography on paper strips, and a number of solvents may be employed ${ }^{2}$. This was confirmed with acetone - a solvent easily separated from glycerol by distillation. It was found, however, that when the same solvent was employed in conjunction with large samples and columns of cellulose, glycerol could not be easily separated from sugars or the fermentable constituents of molasses ; but excellent separation was obtained when alumina was used as adsorbent under the conditions described below, and the glycerol could be determined in the eluate by oxidation with sodium metaperiodate and direct titration of the formic acid produced ${ }^{3}$.

The preliminary experimental work was carried out employing samples of molasses to which known amounts of glycerol were added. In addition to the unfermentable constituents and residual unfermentable organic impurities which are present in formented liquors, molasses also contain large concentrations of fermentable sugars which cause serious interference with the 'periodate' procedure for glycerol. This imposed more rigorous conditions on the chromatographic procedure. In order to avoid strong retention of glycerol by the other constituents of fermentation solutions, it was found necessary to add a small amount of acetic acid to the solution of the sample and to the solvent employed for extraction.

The chromatographic method involves the preparation of a column of coarse-grade cellulose powder (2.5 gm.) (Whatman), which acts as a support for chromatographic alumina $(5 \mathrm{gm} .)^{4}$. Sufficient of the sample is taken to give up to about $0.5 \mathrm{gm}$. glycerol. It should contain about $3 \mathrm{ml}$. water, its volume being $5 \mathrm{ml}$. (approximately). Sulphite fermentation solutions analysed in this laboratory contained glycerol in concentrations up to 12 per cent. After addition of sodium sulphite $(0.5 \mathrm{gm}$.$) , sodium acetate (1 \mathrm{gm}$.) (these compounds assist in the retention of sugars and impurities by the adsorbent) and acetic acid $(0.1 \mathrm{ml}$.) to the sample, the resulting solution is mixed with alumina (15 gm.) and the mixture then transferred to the prepared column. The glycerol is eluted with $250 \mathrm{ml}$. of solvent (acetone containing 5 per cent $\mathrm{v} / \mathrm{v}$ water and 0.05 per cent $\mathrm{v} / \mathrm{v}$ glacial acetic acid).

It was found that there is a small but constant retention of glycerol by the alumina adsorbent; but this difficulty was easily overcome by standardizing the caustic soda solution for the procedure, using 1 gm. molasses to which a known amount of glycerol had been added.

Employing the procedures described, typical results for the recovery of glycerol from mixtures with Cuban blackstrap molasses are given in the accompanying table. Similar results were obtained for fermentation liquors to which known amounts of glycerol had been added.

\begin{tabular}{|c|c|c|c|}
\hline $\begin{array}{l}\text { Weight of } \\
\text { molasses } \\
\text { (gm.) }\end{array}$ & $\begin{array}{l}\text { Weight of } \\
\text { glycerol added } \\
\text { (gm.) }\end{array}$ & $\begin{array}{c}\text { Titration } \\
\left(\mathrm{ml} .0^{\circ} N\right. \\
\mathrm{NaOH})\end{array}$ & 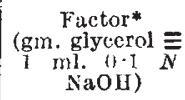 \\
\hline $\begin{array}{l}1 \\
1 \\
1 \\
1 \\
1\end{array}$ & $\begin{array}{l}\wedge \text { il } \\
0 \cdot 7500 \\
0 \cdot 3333 \\
0 \cdot 2499 \\
0 \cdot 0833\end{array}$ & $\begin{array}{r}0 \cdot 4 \\
80 \cdot 4 \\
35 \cdot 8 \\
27 \cdot 0 \\
9 \cdot 1\end{array}$ & $\begin{array}{l}0 \cdot \overline{0094} \\
0 \cdot 0094 \\
0 \cdot 0094 \\
0 \cdot 0096\end{array}$ \\
\hline
\end{tabular}

* Theoretical value $=0 \cdot \operatorname{cog} 2$ (value which would be obtained in the complete absence of glycerol hold-up).

A mixture of $0.1 \mathrm{gm}$. each of sucrose, glucose and mannitol gave a titration of only $0 \cdot 3 \mathrm{ml} .0 \cdot 1 \mathrm{~N}$ sodium hydroxide. The total amount of material extracted from a mixture of $0.3 \mathrm{gm}$. each of these compounds was less than $1 \mathrm{mgm}$., whereas when cellulose alone was used $80 \mathrm{mgm}$. was extracted.

The method has been applied to the analysis of solutions from the alkaline fermentation process of Eoff, Lindor and Beyer ${ }^{5}$.

Full details of this work will be published at a later date.

Research Department, Nobel Division,

Imperial Chemical Industries, Ltd., Stevenston, Ayrshire.

$$
\text { Sept. } 26 .
$$

'Neish, A. C., Can. J. Research, B, 28, 535 (1950).

${ }^{2}$ Hough, I., Nature, 165, 400 (1950).

${ }^{3}$ Iirskine, J. W., et al., Analyst (In the press).

4 Ryan, IW., and Williams, A. F., Analyst, 77, 293 (1952).

- Roff, .T. $k$., Linder, W. V., and Beyer, G. F., Indust. Eng. Chem. 11, $842(1919)$ 